Article

\title{
Achieving Sustainable Nitrogen Management in Mixed Farming Landscapes Based on Collaborative Planning
}

\author{
Andreas Aa. Christensen ${ }^{1, *}$, Peter S. Andersen ${ }^{1}$, Chris Kjeldsen ${ }^{2}$, Morten Graversgaard ${ }^{2}\left(\mathbb{D}\right.$, Erling Andersen ${ }^{1}(\mathbb{D}$, \\ Kristoffer Piil $^{3,4}$, Tommy Dalgaard ${ }^{2}{ }^{(D}$, Jørgen E. Olesen ${ }^{2}{ }^{(1)}$ and Henrik Vejre ${ }^{1}$ \\ 1 Department of Geosciences and Natural Resource Management, University of Copenhagen, 23 Rolighedsvej, \\ DK-1958 Frederiksberg C, Denmark; stub@ign.ku.dk (P.S.A.); eran@ign.ku.dk (E.A.); hv@ign.ku.dk (H.V.) \\ 2 Department of Agroecology, Aarhus University, Blichers Alle 20, 8830 Tjele, Denmark; \\ chris.kjeldsen@agro.au.dk (C.K.); morten.graversgaard@agro.au.dk (M.G.); \\ tommy.dalgaard@agro.au.dk (T.D.); jeo@agro.au.dk (J.E.O.) \\ 3 SEGES, Danish Agriculture and Food Council, 8200 Aarhus, Denmark; kristoffer.piil@aalborg.dk \\ 4 The Limfjord Council Organization, 9400 Nørresundby, Denmark \\ * Correspondence: anaach@ign.ku.dk
}

Citation: Christensen, A.A. Andersen, P.S.; Kjeldsen, C.;

Graversgaard, M.; Andersen, E.; Piil, K.; Dalgaard, T.; Olesen, J.E.; Vejre, H. Achieving Sustainable Nitrogen Management in Mixed Farming Landscapes Based on Collaborative Planning. Sustainability 2021, 13, 2140 https://doi.org/10.3390/su13042140

Academic Editor: Fabio Bartolini

Received: 15 September 2020

Accepted: 8 February 2021

Published: 17 February 2021

Publisher's Note: MDPI stays neutral with regard to jurisdictional claims in published maps and institutional affiliations.

Copyright: (c) 2021 by the authors. Licensee MDPI, Basel, Switzerland. This article is an open access article distributed under the terms and conditions of the Creative Commons Attribution (CC BY) license (https:// creativecommons.org/licenses/by/ $4.0 /)$.

\begin{abstract}
Regulation of nitrogen $(\mathrm{N})$ loss from the agri-environment is a global challenge with dire consequences for food production and environmental management. This is also the case in Denmark where regulation largely relies on general measures for reducing $\mathrm{N}$ inputs. These measures have significantly reduced nitrogen emissions, but further reduction is needed to achieve sustainable low levels of $\mathrm{N}$ transport to freshwater and marine ecosystems in compliance with standards set by the EU Water Framework Directive. As an alternative to general regulation, we tested a watershed-based, collaborative planning approach, engaging stakeholders in solution identification. Six watersheds with substantial agricultural production were used as test areas. A collaborative planning process of two stakeholder workshops embedded within a scenario formulation process was executed. Stakeholder inputs about possible, desirable and sustainable futures were used to formulate scenarios, for which $\mathrm{N}$ reduction effects were calculated. Upon conclusion of this process, results were assessed using a structured evaluation method. Results indicate that the process we tested was successful in terms of (1) engaging relevant stakeholders, (2) providing relevant data, (3) achieving processual flexibility, (4) including local knowledge and (5) facilitating a creative and explorative process. On this basis, suggestions for improving collaborative planning processes are provided.
\end{abstract}

Keywords: landscape ecology; rural planning; agriculture; watershed; agri-environment; evaluation

\section{Introduction}

Sustainable agricultural systems are characterized by patterns of land use which are economically viable and adequately address society's demand for food and fibre, while ensuring long term resource conservation by protecting the integrity of ecosystems $[1,2]$. However, the impact of industrialized farming on the environment in terms of eutrophication is considerable [3,4] and, in most western countries, current policies are likely to be insufficient to meet stated goals $[5,6]$. Environmental problems stemming from farming in Denmark are no exception [7]. Loss of nitrogen $(\mathrm{N})$ from arable land to the terrestrial and aquatic environment has been a persistent problem for the farming sector in Denmark for almost half a century [8].

The magnitude of the $\mathrm{N}$ problem is reflected in the extent of mitigation efforts and societal costs associated with its regulation. In Denmark, $\mathrm{N}$ regulation has been the subject of national legislation, EU legislation and directives, economic incentives and statutory planning spanning four decades [9]. Specific regulatory measures have mainly followed the command and control model [10], and have mainly been based on regulating $\mathrm{N}$ input at farm level, focused on, e.g., crop dependent fertilizer norms, improving manure storage 
facilities and regulating timing of fertilizer and manure applications [11]. The regulation has primarily taken point of departure in general measures. The same rules have been applied to the entire farmed area in the whole country. Some voluntary measures have also been applied to combat $\mathrm{N}$ losses, most often associated with agricultural subvention policies of the EU [12,13]. Here we report on the evaluation of a series of case study experiments designed to test the usefulness of regulating $\mathrm{N}$ based on a bottom-up approach employing participatory planning processes, which has not previously been tested in practice in Denmark. Planning processes were investigated using a self-evaluation method designed to test evaluation criteria proposed in the literature against empirical experience accumulated through case studies. On this basis, we analyse and discuss the relevance of evaluation criteria for assessing participatory planning processes in the context of $\mathrm{N}$ management in agricultural landscapes.

\subsection{The Role of Statutory Planning in N Policies: The Danish Policy Context}

Statutory planning anchored in the Danish Planning Act [14] has been a mainstream environmental and $\mathrm{N}$ regulation tool in Denmark during the last four decades, also in the agri-environmental sector [15]. Designated areas for wetland restoration, targeting of mechanisms in the EU agri-environmental schemes, and designation of groundwater protection areas, were all directly or indirectly related to $\mathrm{N}$ losses from farms and partly anchored in the EU Nitrate Directive [16]. Apart from the Planning Act, several other acts require employment of spatial planning tools relevant to the farming sector, including the Nature Protection Act [17], and the national legislation implementing the EU Habitats Directive [18] and the EU Water Framework Directive [19].

\subsection{N Regulation under Pressure}

General regulation of the Danish agri-environment, and in particular the regulation of $\mathrm{N}$, has been heavily criticized for its insufficiency in providing sustainable solutions [20]. A wide array of aspects of sustainability have been subject to critical scrutiny: the lack of cost-effectiveness, the lack of social inclusion and the lack of results in terms of meeting standards for ecological quality [21]. After two decades with successes in alleviating the eutrophication of the aquatic environment, the top-down oriented regulatory measures have proven insufficient to reduce losses further [11]. Lack of transparency, lack of sufficient detail in regulation, failure to take local geographical variation into account and lack of public participation has put mainstream regulation based on statutory planning and legislation under pressure to achieve further reductions in $\mathrm{N}$ leaching $[22,23]$.

\subsection{Shortcomings of Statutory Planning}

Statutory planning has been criticized for being reactive by nature, often inflexible, and unsuitable to induce an active development of a land area [24]. The knowledge base for statutory planning has been denounced as being too technical, relying too much on professional knowledge and black box modelling, excluding the employment of local knowledge. The Danish planning practice of designating areas with restrictions without action plans to follow up on these designations has been challenged. Further, the focus on single sectorial interests, which is common in statutory planning, is problematic. The plans do not always reflect upon how different functions of the physical environment can be integrated, and the scale at which the designations are delineated is often too coarse to deal with detailed local landscape challenges.

A major shortcoming of the central regulatory tools is the insufficient involvement of citizens and other actors. Formal hearing processes often result in the so-called "Not In My Back Yard (NIMBY)" attitude [24]. The NIMBY reaction, in combination with new citizen science approaches to data production becoming available, perceived lack of integration with local knowledge and persistent requests for more legitimacy in planning has fostered a new focus on how citizens and local communities can be involved in more constructive dialogues about plans and transformation processes [25-28]. Various conventions, such as the 
Aarhus Convention [29], require the involvement of citizens in spatial planning and natural resource management. Despite the democratizing efforts of statutory planning providing more citizen involvement and transparency, participatory planning, including hearings, are arguably still not creating a suitable planning environment. Information sharing is restricted, public involvement is limited and win-lose solutions are promoted [30].

\subsection{Identifying a Proper Scale of Regulation}

Consistent discrepancies between the spatial scale of regulation and planning on the one hand, and the ecological problems that authorities seek to intercept on the other, is a central problem for $\mathrm{N}$ pollution in the agri-environment [22,31]. Neither statutory planning nor any other regulatory tools have so far been able to solve this mismatch in Denmark, where $\mathrm{N}$ losses typically originate from numerous fields managed by several farmers. Due to the $\mathrm{N}$ flow paths in the landscape and hydrosphere, the impacts of $\mathrm{N}$ losses are mainly found in the aquatic system, not least in the shallow coastal waters of Denmark, and typically at a distance from the $\mathrm{N}$ source. On this basis, it can be argued that potential solutions to the $\mathrm{N}$ problem are likely to be identified by taking point of departure in more ecologically meaningful units.

An example of a meaningful spatial unit is landscapes [22], another is watersheds [32], which are also part of an important principle within the EU Water Framework Directive [19]. The logic behind management in landscapes is that input factors ( $\mathrm{N}$ effects of land use) are distributed according to patterns of land use extending and repeating across landscapes, making it possible to address a coherent area where farm units engage in the same pattern of land use by making landscapes the unit of analysis. As such, the landscape approach makes it possible to focus on the agricultural land use system rather than land use units and farm units individually [33]. On the contrary, but possibly with the same effect, the logic behind management in watersheds is that polluters (i.e., farmers) within a watershed share the same recipient, meaning that the effects of their practices are interdependent in terms of environmental impact. As such, the watershed approach aims at managing the totality of impacts affecting the same recipient, meeting the scale of the output effect of land use-for example, based on a common plan. However, from a polluter-pays perspective, individual polluters must be identified, and each legal unit of polluters must be targeted individually [34]. This makes it difficult to implement regulation and planning processes at the scale of either landscapes or watersheds. Some examples exist, for example, with respect to groundwater protection. Here, vulnerable aquifers have been the point of departure for designations and regulation of agriculture aiming at relieving aquifers of nitrate leaching [35]. In this paper, we evaluate an approach in which we used units of analysis (case areas) characterized by spatially coinciding watershed and landscape boundaries (by approximation), making it possible to examine the potentials of using ecologically relevant spatial units to plan $\mathrm{N}$ management in agriculture [22]. In this context, we further sought to solve the challenge of polluter-individualization mentioned above by providing spatially explicit leaching estimates. In this way, we were able to distribute impacts on fields within farm units while maintaining a system-wide perspective on the problem of $\mathrm{N}$ pollution within the watershed landscapes as a whole and facilitate identification of holistic solution scenarios [22,23,36,37].

\subsection{Collaborative Planning and Place Based Solutions as Alternative}

As a reaction to the criticism of statutory planning, the so-called place-based collaborative planning approach has gained momentum in theory and practice. This planning approach has its roots in urban planning and is focused on the development of local places, but this place-making focus has been applied in rural landscapes as well $[15,38]$. The place-based approach is characterized by being strategically focused in that it explicitly identifies goals and targets, thereby prioritizing some things over others. Given the fact that not everything can be taken into account in planning, acting strategically in this way is often a necessity when dealing with trade-offs between outcomes. This is in contrast 
to the statutory planning approach, characterized by a reactive and passive mapping of coinciding and overlapping interests and resources. Formulating strategic priorities also means taking politically and locally momentous decisions about direction and selection of projects and targets, and therefore the place-based approach entails an important aspect of collaboration in planning, a focus that has been given much attention in the last three decades [39].

Bentrup summarized the benefits of collaborative planning as improving relationships among stakeholders and minimizing the risk of reaching an impasse [30]. Further, a broad analysis of the planning issues may improve the quality of the solutions, the involved parties may gain increased ownership to the solution, and willingness to implement plans may increase. Various planning projects have proven this to be at least partly true [13,15]. These projects have proven that citizens in collaboration with the local municipal administrations can transform their own environments in order to strengthen recreation, livelihood and nature management. As such, collaborative planning and place-based approaches may provide an interesting option in the search for alternatives to general regulation of farming. The main research theme addressed in this paper is how the implementation of such processes of intervention and dialogue in practice can be evaluated. Secondly, we aim to discuss whether participatory planning can substitute or supplement statutory planning and whether scenarios developed in participatory processes are useful as a tool to communicate targets instead if using rules to communicate limits.

\subsection{Research Aims}

Many collaborative planning processes have focused on rather soft environmental issues, with low stakes and low personal risk of the involved stakeholders. Few collaborative planning projects have been aimed at solving hard environmental problems, where at least some stakeholders have critical interests pertaining to their businesses, welfare and jobs. Nitrogen regulation in the agri-environment is such a case, where stakes are very high among farmers; the conflict level with other stakeholders is high and the societal interests monumental. In this study, we test whether a collaborative approach is applicable on such controversial issues in the agricultural landscapes of Denmark. As there are no opportunities to circumnavigate present day legislation, the test was limited to the preparation and negotiation phase and ended when plans had been formulated by stakeholders through the planning process. We therefore report on an evaluation of the planning process itself rather than, for example, its outcomes in terms of land use change. On this basis, we discuss criteria relevant for assessing the success of deliberation and negotiation processes. This approach is described below.

Neither the contemporary Danish regulation nor the administrative tradition are in favour of a bottom-up planning and regulation approach, which relies on self-governance in local communities and on trust rather than control mechanisms. On the other hand, the Danish agricultural sector has a long history of cooperatives and negotiated solutions. However, due to the constraints of the existing regulation system, it was not feasible to conduct a real life case study, and the general ambition of our research was therefore to test a collaborative planning process in a context resembling a real-life situation as closely as possible. We wished to test if a collaborative planning process could be staged within which relevant stakeholders could develop locally adapted, targeted regulation of $\mathrm{N}$ as a substitution for the conventional national regulation as it has unfolded over the past three decades. Further, our aim was to evaluate this local planning process against the principles summarized above regarding planning dimensions and communication. An important element of the research approach was to develop an interactive GIS-based planning tool to formulate scenarios for use in the local planning processes [22]. The tool enabled participants to assess the effects on the environment of their decisions regarding regulation and land use changes, both at the scale of individuals and at the scale of landscapes/watersheds, thereby underpinning key dialogues. 
Key challenges in the planning process were to identify a suitable spatial scale, to identify an appropriate group of stakeholders, to orchestrate deliberative processes, to test scenario tools and to test how far local stakeholder groups could get on the pathway towards formulating local solutions to the $\mathrm{N}$ loss problem as an alternative to general regulation. The test of integrating local knowledge with expert knowledge in a synthetizing input to a local environmental planning process was a separate issue, as this integration is critical in the decentralising effort of directing regulation from the statutory organisation to non-statutory ones [40]. Criteria for successful integration of local and expert knowledge are double-sided, given that integration processes can be evaluated both based on (1) the relevance and precision of the resulting data in a general scientific context and (2) the experienced degree of relevance of the data in a local context [22]. Thus, for outside expertise to inspire and inform local solutions, both criteria have to be met.

\subsection{Theoretical Reference Points for Collaborative Planning}

A successful collaborative planning process is complicated to stage, and there are no prescribed methods; rather, there are a number of heuristics regarding involvement, communication, commitment and building mutual respect among stakeholders. According to Agger and Hoffman, there are certain preconditions necessary to create a successful collaborative arena [41]. Firstly, a diversity of interests and values must be present in order to ensure a democratic and legitimate decision process and to create a dynamic atmosphere. Secondly, the participants must be mutually dependent (which does not imply symmetric relations among participants). Thirdly, there must be room for dialogue - the ideal is a power free room where only arguments count (see also [42]). Finally, professional lingo must be absent from the dialogue, and there must be mutual respect and willingness to listen, despite the presence of different professional languages and backgrounds.

Healey stressed that a key aspect of the collaborative planning approach is the inclusion of relevant actors and the establishment of an arena for the planning process [43]. Accordingly, Healey suggested four dimensions of a collaborative planning process. The dimensions are mutually dependent, but not necessarily sequential. The dimensions comprise: (1) Mobilisation of interest, including a focus on the spatial entity as a whole; (2) Scoping the situation, i.e., uncovering the opportunities and identifying the direction of the actions; (3) Mobilising resources, including explicit and implicit knowledge, systematic/analytical and experimental/practical knowledge; and (4) Generating frames and ideas, and selection of strategic projects. This collaborative planning concept was adopted from urban contexts; hence, it is worth emphasising that actors, capacities, institutions and planning issues may be very different in rural settings as compared to urban ones, though challenges and processes in rural areas may resemble those of urban areas. Important differences between urban and rural contexts include the role of private land owners, the role of the farming sector, population density and the often marginal location of rural areas in relation to administrative centres [44].

Collaborative planning projects have been implemented in action-oriented research projects, which have demonstrated potentials and limitations of collaborative planning in rural areas and watersheds. There are experiences from Denmark with collaborative planning in rural areas at several scales and with several planning issues, and some general outcomes can be emphasized. In most cases, both the farmer as an individual and the farming sector in general are critical players in the solution of planning issues in rural districts $[24,45,46]$. However, the role of the farmer and the farming sector may be extremely complicated. The main reason for this is the multifaceted role of the farmer in a modern society [44,47]. As an owner of a farm property, the farmer behaves as a territorial individual administering a property. The farmer is also a producer of farm products and hence a player on a highly competitive global market. Finally, the farmer is a citizen in a local community with positive and negative interactions with fellow citizens [48]. Due to these different roles, which may be distributed among individuals and businesses, the farmer is an individual split among many interests, and as a player in the local community 
he or she is divided between several agendas-a global market agenda, a national and local environment agenda and a local livelihood agenda [44].

Danish experiences indicate that rural communities, given the right conditions, are capable of formulating visions for their territories, and in many instances capable of implementing projects. However, more exact planning, including the design of spatially explicit plans at local scales involving specified measures, is more problematic and will often require expert guidance. Further, public authorities are important in the financing of projects and as an alliance partner when it comes to formal permissions. The current record of projects also indicate that the issues dealt with in collaborative planning for rural areas, where agriculture plays a dominant role, usually remain in the category of soft environmental issues with relatively low conflict levels and issues that do not target agricultural production or emissions directly. These themes are typically related to improving village settlement-structures, and improving or safeguarding landscape functions such as recreation, aesthetics and nature conservation, often embedded in broader strategies pertaining to local and regional development, tourism and liveliness [24]. All of these themes imply potential conflicts between landowners and farming practices, but at a relatively low intensity. Furthermore, planning of this kind does not question the individual decision making authority of farmers, which could be the case in planning for reduced $\mathrm{N}$ loss. As such, there are no previous Danish experiences from collaborative, place based planning processes when it comes to hard environmental problems such as pollution of groundwater and surface waters, eutrophication of terrestrial ecosystems and drift of pesticides. The common denominator of these problems is strong economic interests among farmers as key stakeholders and a high conflict level among stakeholders at different spatial and organisational scales. This is in line with the findings of Linnenluecke et al., who, in a comprehensive review, concluded that there is a lack of planning approaches that connect planning to ecological limits [49].

\section{Description of the Planning Process and Case Areas}

\subsection{Case Study Approach and Methodological Limitations}

The case based approach used in this study is inspired by the work of Flyvbjerg [50]. Working with case studies require some basic precautions in terms of representativeness, and broader generalizations must be made with some caution. Our case studies were designed to simulate real-life planning situations. Cases were selected where there were actual problems pertaining to $\mathrm{N}$ losses from agricultural land use and concerns for the environment. Case areas were delimited based on watershed boundaries and landscape factors. In each case area, land owners, NGOs, authorities and other stakeholders were asked to deliberate and negotiate solutions to a common challenge; the regulation of $\mathrm{N}$. Despite these attempts to mimic a real situation, the role of case areas within a research project imply some deviations from a real-life situation. Firstly, more resources were allocated to the dialogues than in a real-life situation, and researchers were present as facilitators and observers. Secondly, although the suggested regulatory tools were well known to the participants, they were used in a hypothetical way because they had not yet been legally approved in Denmark, and as a result the stakeholders gathered had no formal power to implement a plan or strategy resulting from the planning process.

\subsection{Case Areas}

The planning method tested was subject to experimentation in six case areas. As a whole, the six areas represented the variation in landscape attributes across Denmark with respect to soil characteristics, hydrology, farm structure, distribution of nature areas and environmental conditions. Cases were selected based on these variables to ensure a high degree of variation in the sample with respect to local conditions for agriculture. The case areas constituted entire watersheds. A watershed is often considered a suitable planning unit in natural resource management including management of water quality $[30,33]$. The watersheds were chosen with a view to ensure that a single coherent land use pattern 
dominated within each, so that we would be dealing with a single landscape system. We decided that the size of the case watersheds should be limited to ensure a realistic planning process where the number of stakeholders was not excessively large, and there was an actual chance of identifying a local community. The case areas should have agriculture as the dominant land use class, and they should be challenged by insufficient regulation with respect to reaching stated $\mathrm{N}$ targets. Apart from these criteria, the choice of case area was influenced by local will to cooperate at the level of municipal authorities.

The location and extent of the case areas is outlined in Figure 1. Prior to the workshops, we conducted a detailed mapping of the case areas, including an overview of soil, terrain, land cover, land use and hydrology. The subsections below summarize key characteristics of the case areas.

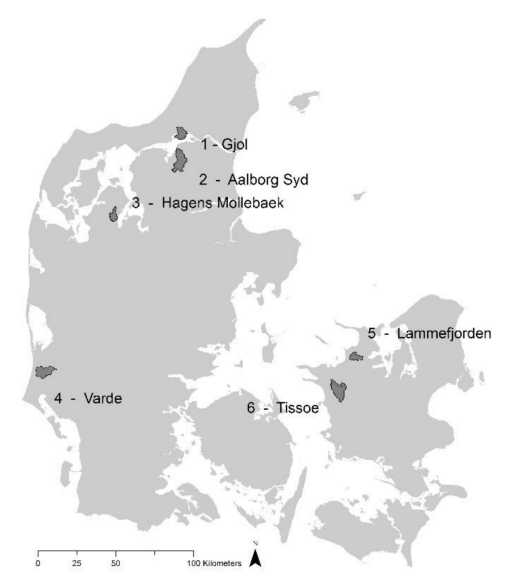

Figure 1. Location and extent of case areas in Denmark.

\section{(1) Gjøl}

The case area Gjøl in northern Jutland is located on a lowland plain extending into the Limfjorden fjord system. Since the early 19th century, the area was regularly flooded, and the creation of dikes and pumped drainage systems has resulted in the formation of the current peninsula. The area has a landscape with a very varied terrain dominated by sandy soils. This makes the area more suitable for crops with general low yields. Agriculture is the primary land use in the area, but nature areas cover a relatively large part of the southern area.

\section{(2) Aalborg Syd}

The case area of Aalborg Syd in north-eastern Jutland is situated in a landscape dominated by sand and sandy loams, and the terrain is relatively hilly except from the flat northern tip of the area. It is an area well suited for agriculture with average soil conditions. Surface water from the area drains into the nearby Limfjorden fjord system. The dominant land use is intensive agriculture, and the area has a low to medium proportion of nature areas.

\section{(3) Hagens Møllebæk}

The case area Hagens Møllebæk in north-western Jutland is located in a landscape close to Skive Fjord, which, in the north, flows into the greater Limfjorden fjord system. The soils of the area contain both clay and sand; the terrain is relatively flat, apart from steep slopes near watercourses where postglacial erosion valleys intersect the landscape. The area is overall very suitable for agriculture and has the highest proportion of rotational cropland and the lowest proportion of nature areas of the six case areas.

\section{(4) Varde}

The case area of Varde is located in western Jutland in a landscape that is the least intensively used among the case areas. The area has the highest proportion of nature per 
area. The terrain varies along a gradient, from west to east, encompassing a zone of hilly, wet and sandy parts in the west with complex land use patterns, whereas the more fertile east is dominated by agriculture. The western part of the area contains large conservation and recreation areas including the Filsø lake system and number of conifer plantations created since the 18th century to control erosion and aeolic deposition of sand.

\section{(5) Lammefjorden}

The Lammefjord case area in north-west Zealand is located in a reclaimed landscape, which was embanked and drained at the beginning of the 19th century. This resulted in the creation of a fertile agricultural production surface with homogenous, low lying flat terrain. These conditions, combined with a relatively high soil clay content and efficient artificial drainage systems, make the area favourable for intensive agriculture. This is the dominating land use in the area, whereas nature covers a small fraction of the area.

(6) Tissø

The Tissø case area is located in the western part of Zealand. It has well drained undulating to hilly terrain and drains into the nearby Tissø lake, which is included in the case area. Along the lake, the landscape is dominated by a stretch of bog-basins and forest patches. A large proportion of the case area is covered by water bodies, forest, and grazed open nature areas. The soil is mainly composed of clays, with organic soils covering most of the wetland area towards the north. The terrain is highly varying, which is reflected in the varied land use.

\subsection{Identification of Stakeholders}

Stakeholders were recruited from among local farmers, NGOs, businesses and authorities to assemble a broad array of agents representing local land use interests, making it possible to mobilize local knowledge and access local perspectives on the future of the area. The overall selection criteria were that stakeholders ideally should represent interests pertaining to farming, landscape and/or nature conservation. In all case areas, it was a criteria for the planning process that the following stakeholder groups were represented: land owners (primarily farmers), citizens (as organized in NGOs representing interests such as nature conservation, ornithology, angling, etc.), authorities (municipalities, state forest district officers), local enterprises related to landscape and farming (such as tourist businesses and farm product manufactures) and representatives of the agricultural extension services (farm consultants). It should be noted that, in all cases, there was a majority of farmers among the participants due to great interest among local land holders. There were fewer representatives from the local authorities.

\subsection{Workshops and GIS Based Scenarios}

The stakeholders were engaged in an iterative scenario-driven land allocation game [23], which was anchored in two stakeholder workshops embedded within a process of articulating landscape and land use development scenarios, in which a GIS based tailor-made landscape model was a central tool [22]. The landscape model tool consisted of an interactive, spatially explicit interface showing a series of maps detailing (1) current land use and (2) the estimated effects on N-leaching derived from land use information. The tool was designed to allow participants to interactively experiment with land use scenarios by drawing new field divides and reassigning land use parameters graphically and, on this basis, derive new estimates for leaching from the underlying modelling framework.

All workshops followed the same procedure. Invitations to stakeholders to participate in the initial project presentation and workshop were distributed in 2014. The first workshops in the case areas were held the same year. As the first step in the process, all stakeholders were invited to participate in an excursion by bus, during which the local landscape and farming practices were presented and discussed. The excursion was staged to facilitate a degree of alignment of the participants' views and experiences of the landscape and farming situation in the area. Subsequently, the scenario process was introduced. 
A member of the research team presented the concept of the participatory process and the linkage to the $\mathrm{N}$ regulation, including the option of formulating comprehensive local plans for the community's landscape. Inputs to future scenarios were produced during group discussions.

The inspiration from the scenario workshops were used over the following years using the landscape tool, a GIS bases spatially explicit decision support tool developed for this purpose, as described above in Section 1.6. Outcomes from the stakeholderdefined scenarios were presented at a concluding second round of workshops in 2016 and 2017, where stakeholders were invited to comment and modify the scenarios. The same participants were invited, and they were given the chance of discussing the outcomes in terms of reduction in $\mathrm{N}$ losses and associated landscape changes.

\subsection{Future Land Use Scenarios and the Use of a Landscape Tool}

From the beginning, we decided that scenarios should be used as the key means of communication. Formulation of alternative scenarios for a given context can be used to open discussions as to preferred development pathways, and this may elucidate conflicts and help balance interests. The workshops were intended to support such a scenario development process. In order to achieve a close alignment between workshop visions for the future, formulated as spatially explicit scenarios, and N-flows (typically calculated/estimated in spreadsheets), we introduced a tailor-made landscape modelling tool able to record scenarios and predict likely N-outcomes from scenario input. This platform enabled local stakeholders to engage directly in developing landscape scenarios in the context of $\mathrm{N}$ management. The model allows the users to evaluate the landscape impacts of suggested changes of land use, crop rotation, and fertilizer application through a geographical interface, and to calculate estimates of the associated changes in $\mathrm{N}$ leaching and loadings to the aquatic environment [22]. The dNmark landscape tool contains detailed information of the most important landscape characteristics in relation to $\mathrm{N}$ leaching, e.g., soil type, hydrology and nitrogen retention. This allows the users to take the variation of the landscape as well as the interests of local stakeholders into account when suggesting future $\mathrm{N}$ management solutions.

\section{Materials and Methods}

\subsection{Evaluation of the Planning Process-Success Criteria}

The central methodological question of our study is the choice of evaluation regime. Evaluation of planning processes is challenging in several ways. In general, the outcome of planning processes should be evaluated towards reasonable standards but, in a situation like the one studied here, processes cannot over-perform because the planning process being tested is not implemented after plans are formulated. Hence, the central evaluation criteria used have to focus on the process and the outputs of the workshops, but not of the outcomes in terms of resulting effects in the landscape. Therefore, we developed an evaluation method focusing solely on the collaborative process, i.e., the ability of researchers, using certain methods, to facilitate a productive and efficient dialogue process around the topics needed to be discussed. We focused on the researchers rather than stakeholders because we consider it likely that, given the absence of tangible outcomes, the discussions would be largely irrelevant to local stakeholders. For the planning process, we stressed the following success criteria: (1) identification of the right stakeholders, (2) engagement of stakeholders in the dialogue, (3) the degree to which stakeholders provide inputs to the scenarios, and (4) whether the stakeholders accept the premises and participate with enthusiasm. Further, alignment of the stakeholder group in terms of shared goals and inclusion of local knowledge were critical success criteria. The creation of a collaborative, transparent and comfortable atmosphere for all stakeholders was also a central evaluation parameter. 


\subsection{Choice of Evaluation Criteria}

As a collaborative planning research experiment, we wished to evaluate the process and the outcome towards sets of well-defined evaluation criteria. As a point of departure for our selection of evaluation criteria, we reviewed several studies which evaluate collaborative planning processes in different contexts. We chose four sets of evaluation criteria, as mentioned in detail below: The Selin and Chavez model, as cited by Bentrup [30], the Fahnle and Tyrväinen approach [51], the Vacik et al. approach [52] and the Cullen et al. approach [53]. The evaluation criteria were included in a gross list, which was the point of departure for an evaluation seminar with the participation of 15 scientists who were all involved in the planning project. In combination, Tables 1 and 2 in the Results Section list the total set of criteria considered.

Table 1. Evaluation criteria selected as relevant ${ }^{1}$.

\begin{tabular}{|c|c|c|}
\hline$\#$ & Name & Key Question \\
\hline 1 & Existing networks & Do networks already exist on which the process can build? \\
\hline 2 & Incentives & Are there incentives in place for engaging in the process? \\
\hline 3 & Identification of stakeholders & $\begin{array}{l}\text { Does the process help identify relevant legitimate } \\
\text { stakeholders? }\end{array}$ \\
\hline 4 & Facilitation of consensus & $\begin{array}{l}\text { Does the process help approach consensus among } \\
\text { stakeholders? }\end{array}$ \\
\hline 5 & Recognition of interdependence & $\begin{array}{l}\text { Does the process help stakeholders recognize mutual } \\
\text { dependence? }\end{array}$ \\
\hline 6 & Perception of benefits & Does the process support stakeholders in realizing benefits? \\
\hline 7 & Common problem identification & $\begin{array}{l}\text { Does the process help form consensus regarding the } \\
\text { initiating problem? }\end{array}$ \\
\hline 8 & Identification of coordinator & Does the process include the identification of a coordinator? \\
\hline 9 & Setting of ground rules & $\begin{array}{l}\text { Is it clear in the process how rules of participation are } \\
\text { defined? }\end{array}$ \\
\hline 10 & Establishing goals & Does the process foster a feeling of consensus on the goals? \\
\hline 11 & Exploration of options & $\begin{array}{l}\text { Is the process suited to unfold and formulate alternative } \\
\text { futures? }\end{array}$ \\
\hline 12 & Reaching agreement & Is the process suited to reach general agreements? \\
\hline 13 & Formalization of relationships & $\begin{array}{l}\text { Is the process suited to facilitate formalization of } \\
\text { relationships? }\end{array}$ \\
\hline 14 & Support of creativity & $\begin{array}{l}\text { Does the method foster an environment for creative } \\
\text { thinking and innovation? }\end{array}$ \\
\hline 15 & Increasing transparency & $\begin{array}{l}\text { Does the process support increasing transparency on the } \\
\text { subject? }\end{array}$ \\
\hline 16 & Consideration of experience & $\begin{array}{l}\text { Does the process take into account implicit and/or } \\
\text { indigenous knowledge? }\end{array}$ \\
\hline 17 & Supports gathering interests & $\begin{array}{l}\text { Does the process help gather the perceptions and interests } \\
\text { of all parties? }\end{array}$ \\
\hline 18 & Allows creating collaboration atmosphere & Does the process facilitate a collaborative atmosphere? \\
\hline 19 & Supports negotiation & $\begin{array}{l}\text { Is the process suited to supporting negotiation among } \\
\text { stakeholders? }\end{array}$ \\
\hline 20 & Allows broad involvement & Does the process have potential to engage a large group? \\
\hline 21 & Requires less time in preparing and applying & Is the process quick enough to work in practice? \\
\hline 22 & Can be adapted & $\begin{array}{l}\text { Is the process able to be adjusted to different scales and } \\
\text { needs? }\end{array}$ \\
\hline 23 & Has high useability & $\begin{array}{l}\text { Does the process lead to easily understood and illustrative } \\
\text { results? }\end{array}$ \\
\hline 24 & Handles uncertainty & Does the process allow the consideration of uncertainty? \\
\hline 25 & Handles complexity & Does the process allow the consideration of complexity? \\
\hline 26 & Provisioning of information & Is information of high quality made available in the process? \\
\hline 27 & Improvement of knowledge & $\begin{array}{l}\text { Does the process lead to improved knowledge and a clearer } \\
\text { value base? }\end{array}$ \\
\hline
\end{tabular}


Table 1. Cont.

\begin{tabular}{|c|c|c|}
\hline$\#$ & Name & Key Question \\
\hline 28 & Transactional value & $\begin{array}{l}\text { Do the values gained through participation outweigh costs } \\
\text { for participants? }\end{array}$ \\
\hline 29 & Accessibility of information & $\begin{array}{l}\text { Does the process ensure that all stakeholders are well } \\
\text { informed at all times? }\end{array}$ \\
\hline 30 & Adequacy of inclusion & $\begin{array}{l}\text { Does the process include adequate ways of inviting } \\
\text { informants? }\end{array}$ \\
\hline 31 & Reduction of conflicts & $\begin{array}{l}\text { Do the process and outcomes reduce conflict among } \\
\text { stakeholders? }\end{array}$ \\
\hline 32 & Building social capital & $\begin{array}{l}\text { Does the process produce new relationships and social } \\
\text { capital? }\end{array}$ \\
\hline 33 & Adequacy of information & $\begin{array}{l}\text { Does the process produce information that is useful for } \\
\text { stakeholders? }\end{array}$ \\
\hline 34 & Support of collaborative planning & Does the process increase support of collaborative planning? \\
\hline 35 & Shared purpose & $\begin{array}{l}\text { Is the process driven by a shared purpose driving } \\
\text { participants? }\end{array}$ \\
\hline 36 & Inclusive representation & $\begin{array}{l}\text { Does the process facilitate involvement of all significant } \\
\text { parties? }\end{array}$ \\
\hline 37 & Voluntary representation & $\begin{array}{l}\text { Is the process building on voluntary participation and } \\
\text { commitment? }\end{array}$ \\
\hline 38 & Self-design and co-creation & $\begin{array}{l}\text { Does the process let the participants decide on designs and } \\
\text { decisions? }\end{array}$ \\
\hline 39 & Creative flexibility & $\begin{array}{l}\text { Does the process allow for adaptation and creativity in } \\
\text { problem solving? }\end{array}$ \\
\hline 40 & High quality information & $\begin{array}{l}\text { Does the process incorporate high-quality information into } \\
\text { decision making? }\end{array}$ \\
\hline 41 & Time Limits & $\begin{array}{l}\text { Does the process help in setting realistic milestones and } \\
\text { deadlines? }\end{array}$ \\
\hline 42 & Effective process management & $\begin{array}{l}\text { Is the process coordinated and managed effectively, and in a } \\
\text { neutral manner? }\end{array}$ \\
\hline
\end{tabular}

${ }^{1}$ The table summarizes evaluation criteria defined in the literature and used in the analysis. Criteria 1-13 based on Bentrup (2001), 14-25 based on Vacik et al. (2014), 26-30 based on Faehnle and Tyrväinen (2013), 31-42 based on Cullen et al. (2010). Descriptions and questions were abridged and rephrased to fit the format of this table.

Table 2. Evaluation criteria dismissed as irrelevant ${ }^{1}$.

\begin{tabular}{|c|c|c|}
\hline$\#$ & Name & Key Question \\
\hline 1 & Mandate & Does the group have some kind of special mandate to participate? \\
\hline 2 & Broker & Is there a mediator already in place? \\
\hline 3 & Leadership & Is there a recognized leader/leaders among the participants? \\
\hline 4 & Common vision & Are there already common visions formulated? \\
\hline 5 & Crisis & Is there a crisis which spawns the need for a planning process? \\
\hline 6 & Joint information search & $\begin{array}{l}\text { Is the process suited for the stakeholder group to share } \\
\text { information? }\end{array}$ \\
\hline 7 & Organization of sub groups & $\begin{array}{l}\text { Does the process facilitate formation of sub groups and delegated } \\
\text { tasks? }\end{array}$ \\
\hline 8 & Dealing with constituencies & Is there a defined relationship with constituencies? \\
\hline 9 & Roles assigned & Does the process facilitate assignment of roles to stakeholders? \\
\hline 10 & Tasks elaborated & Does the process facilitate assignment of tasks to stakeholders? \\
\hline 11 & Implementation of strategy & $\begin{array}{l}\text { Is the process suited to formulate strategies that have meaningful } \\
\text { impacts? }\end{array}$ \\
\hline 12 & Compliance & $\begin{array}{l}\text { Does the process lead to strategies that comply with other } \\
\text { strategies? }\end{array}$ \\
\hline 13 & Adaptive management & $\begin{array}{l}\text { Is the process suited to facilitate successfully altering existing } \\
\text { strategies? }\end{array}$ \\
\hline 14 & Independence from expertise & $\begin{array}{l}\text { Is the process useful also in the absence of high levels of } \\
\text { expertise? }\end{array}$ \\
\hline 15 & Independence from IT & Is the process useful without computer based support? \\
\hline
\end{tabular}


Table 2. Cont.

\begin{tabular}{|c|c|c|}
\hline$\#$ & Name & Key Question \\
\hline 16 & Use of quantitative information/values & Does the process allow considering quantitative information? \\
\hline 17 & Use of qualitative information & Does the process allow considering qualitative information? \\
\hline 18 & Meaningful involvement & $\begin{array}{l}\text { Is the process meaningful, seen from the perspective of } \\
\text { participants? }\end{array}$ \\
\hline 19 & Learning in the community & Does the process support learning in the community? \\
\hline 20 & Independence from delineations & $\begin{array}{l}\text { Does the process successfully facilitate work across borders and } \\
\text { sectors? }\end{array}$ \\
\hline 21 & Integrated governance & $\begin{array}{l}\text { Does the process build on and integrate with exiting governance } \\
\text { systems? }\end{array}$ \\
\hline 22 & Cost-effectiveness & $\begin{array}{l}\text { Is the process efficient in terms of results obtained and resources } \\
\text { used? }\end{array}$ \\
\hline 23 & Organizational learning & Does the process help involved organizations improve? \\
\hline 24 & Better Plan & $\begin{array}{l}\text { Does the process help steer local development in a new and better } \\
\text { direction? }\end{array}$ \\
\hline 25 & Better quality of environment & Does the process facilitate improved environmental conditions? \\
\hline 26 & Enhanced decision making capacity & Does the process facilitate growth in decision making capacity? \\
\hline 27 & Local progress & Does the process support sustainable development in the area? \\
\hline 28 & Perceived success & Are the process and its outcomes perceived to be successful? \\
\hline 29 & Reaching agreements & Does the process result in agreements among stakeholders? \\
\hline 30 & Superiority to other methods & Is the process superior to other decision methods? \\
\hline 31 & Creativity and innovation & Does the process produce creative and innovative ideas? \\
\hline 32 & Knowledge and skills & $\begin{array}{l}\text { Do stakeholders gain knowledge, improved skills and better } \\
\text { understanding }\end{array}$ \\
\hline 33 & Second-order effects & $\begin{array}{l}\text { Does the process produce changes that are useful for other } \\
\text { projects? }\end{array}$ \\
\hline 34 & Public interest & Do outcomes of the process serve the public interest? \\
\hline 35 & Clear ground rules & $\begin{array}{l}\text { Does the process include a comprehensive procedural } \\
\text { framework? }\end{array}$ \\
\hline 36 & Equal opportunity & Does the process provide for equal and balanced opportunity? \\
\hline 37 & Principled negotiation & $\begin{array}{l}\text { Does the process operate according to mutually agreed } \\
\text { principles? }\end{array}$ \\
\hline 38 & Accountability & $\begin{array}{l}\text { Is the process making participants accountable in a relevant } \\
\text { context? }\end{array}$ \\
\hline 39 & Implementation and monitoring & $\begin{array}{l}\text { Is there a clear agreement on targets for implementation and } \\
\text { monitoring? }\end{array}$ \\
\hline 40 & Independent facilitation & Is an independent, trained facilitator involved in the process? \\
\hline
\end{tabular}

${ }^{1}$ The table summarizes evaluation criteria defined in the literature and used in the analysis. Criteria 1-13 based on Bentrup (2001), 14-17 based on Vacik et al. (2014), 18-27 based on Faehnle and Tyrväinen (2013), 28-40, based on Cullen et al. (2010). Descriptions and questions were abridged and rephrased to fit the format of this table.

Bentrup used five critical criteria for a successful collaborative planning process: antecedents, i.e., events prior to the planning process being initiated, problem setting, direction setting, implementation and evaluation. A set of detailed evaluation criteria was developed within each of these five general criteria [30].

Faehnle and Tyrväinen suggested four steps in the collaborative planning processes with associated success criteria: knowledge integration (adequacy of high quality information; improvement of the knowledge and value base), meaningful involvement (participatory process worth the effort, accessibility of information, adequacy of opportunities to participate, learning in the community), functioning governance (well-working cross-border collaboration, cost effectiveness of collaboration, organizational learning) and sustainable use of the area as outcome (better plans, better quality of the environment, enhanced collaboration and decision making capacity) [51].

Vacik et al. suggested a 16 step evaluation process with criteria including: Collaborative planning should support creativity and innovation, increase transparency, consider experiences, support the gathering of interests, create a collaborating atmosphere, support negotiation, allow involvement of a high number of stakeholders, require less time in preparation and application, reduce the need of high level of expertise, adapt to different needs, 
reduce need for computer based support, produce understandable documents/results, help to explore/handle uncertainty and complexity and allow the inclusion of quantitative/qualitative information values [52].

Cullen et al. suggested a two-tier evaluation process, divided into process criteria and outcome criteria. The process criteria related to, e.g., perceived successfulness, purpose and incentives, agreement, inclusive representation, reduction of conflict, voluntary participation superiority to other methods, self-design, creativity and innovation, clear ground rules, knowledge, understanding, and skills; equal opportunity and resources; relationships and social capital; principled negotiation and respect; production of information that is useful for stakeholders; accountability; changes in behaviour and relationships that are useful for other projects outside the process; flexibility, adaptation and creativity; public interest; incorporation of high-quality information; understanding and support of collaborative planning; realistic milestones and deadlines; increase of support and understanding of collaborative planning; implementation and monitoring; effective process management and independent facilitation [53]. The choice of relevant criteria from this list of potential candidates depended on the selection process, as described below.

\subsection{Evaluation Process - Choice of Evaluation Criteria and Rating}

All researchers involved in the case study projects participated in a stepwise process of selecting evaluation criteria and evaluating the case study according to the chosen criteria. The process took place during a one day evaluation seminar.

The evaluation seminar comprised the following steps (Figure 2): Preparation, including presentation of the gross list of evaluation criteria; Evaluation phase 1: selection of relevant criteria; Evaluation phase 2: rating of selected criteria; Evaluation phase 3: establishing consensus on evaluation results.

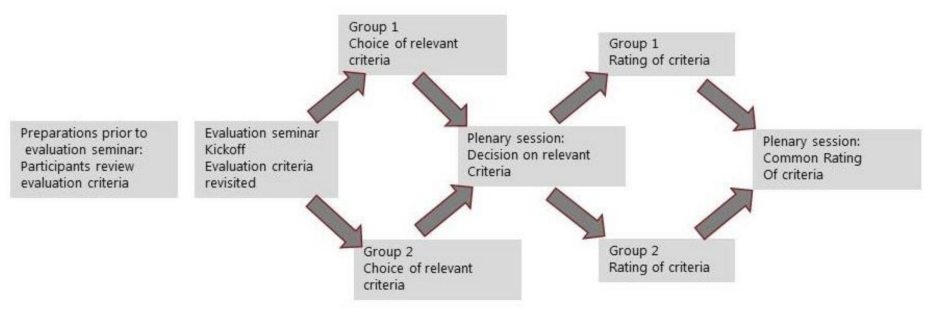

Figure 2. Overview of the method used to select relevant evaluation criteria from among lists of candidates and evaluate the planning process based on structured interdisciplinary deliberation.

Prior to the evaluation seminar, all evaluation criteria from the four chosen studies were listed and explained (Table 1). All 15 participating scientists became acquainted with the list and related papers. The first step in the seminar was to negotiate relevant criteria, i.e., those most suitable for the Danish cases. This was done in two parallel groups in order to nuance the outcome and have a base for comparison. The task at this point was not to evaluate the planning process per se, but to identify criteria that were the most relevant and applicable for our process in light of our success criteria. Further, possible gaps in the list of evaluation criteria were identified.

After reaching consensus with respect to identification of the most relevant criteria, the two parallel groups gathered again, and the chosen criteria were used to evaluate the planning process as a whole, across all six case areas. The two groups were assigned with the task of rating all single criteria, giving scores from 1 to 5 , indicating the degree of success of the planning process. The interpretation of the rating was as follows: Most successful (5), meaning that there is no reason to change; Overall successful (4), meaning that modifications could be done; Neutral (3), meaning that improvements were needed; Partly failure (2), meaning that rethinking of the process is needed; and Complete failure (1), meanimg that the process needs overall rethinking. 
After the group work, the plenary session compared results, registered divergence and negotiated consensus (Figure 2). During the seminar, arguments for giving the ratings were registered.

\section{Results}

\subsection{Identification of the Most Relevant Evaluation Criteria}

The first set of results collected through the evaluation process was a distinction between (1) Relevant criteria for evaluation of the experimental type of collaborative process tested in this study (Table 1) and (2) Irrelevant criteria for evaluation (Table 2). Seen as a whole, Tables 1 and 2 list all evaluation criteria considered and provide a brief indication of their specific meaning and application in the form of key questions for each criteria.

Half of the Bentrup, Faehnle and Tyrväinen and Cullen et al. criteria were dismissed as irrelevant, whereas only 4 of the 16 Vacik et al. criteria were rated irrelevant/non applicable (Table 1). The main reason for excluding criteria was a distinction between process-oriented as opposed to ex-post criteria oriented towards implementation. Another main reason was that redundancy between criteria was evident in some cases. Often we found that the criteria of Vacik et al. covered our situation best.

The Bentrup criteria covering change processes proved less relevant, as we did not have prerequisites to judge the situation in the communities prior to the execution of case studies. The criteria pertaining to implementation, monitoring and evaluation were not applicable as the outcome was not a final implementation-ready plan which could be evaluated.

All the Vacik et al. criteria were rated relevant, those left out being redundant. The Faehnle and Tyrväinen criteria focusing on knowledge integration and meaningful involvement were rated relevant, whereas criteria focusing on governance and outcomes were not found to be applicable, as the criteria dealt with formal relationships. In general, many criteria were found only to be relevant if it was possible to benchmark observations to comparable processes. We did not have any comparable processes to evaluate against, and the process was not part of a formal legal system providing additional or alternative benchmarks. The Cullen et al. criteria were generally rated relevant, but half of them were already covered by others.

\subsection{Most Successful Criteria}

The most successful (score $=5$ ) parameters pertain to stakeholders, the staging of the planning process including the information level and the adaptability of the planning model. The identification and involvement of relevant stakeholders and empowerment of the stakeholders in the planning process was rated high. The important aspect of providing the stakeholders with equal opportunities was also successful. The identification of stakeholders by involving the local community, and by a very inclusive strategy, proved efficient, and stakeholders generally participated with positive interest and commitment.

The planning process was strongly dependent on the availability of data and data processing power, which enabled the stakeholders to formulate explorative scenarios. Hence, it was critical that technical support was available, that the process allowed the inclusion of quantitative and qualitative data, and that data were readily available in an adequate manner and of the appropriate quality. All these factors were rated successful. The planning process allowed the inclusion of quantitative and qualitative information, and there was accessibility of high quality information throughout.

The planning process helped to explore and reduce the complexity of the planning issue related to the $\mathrm{N}$ emissions in question. A part of this was a degree of flexibility in the process, allowing for adaptation and creativity in problem solving. These issues were also rated as very successful. 


\subsection{Moderately Successful}

As a key element in our process, our aim was to include local knowledge in the planning process, both to improve the evidence based environmental management and also to improve the sense of involvement and respect for the local knowledge present among stakeholders. Further, results had to be communicated in a manner which did not require expert knowledge. All these elements were rated rather high $($ score $=4)$. Improvements in the planning process are needed when it comes to the infrastructure of acquiring data from local sources, for instance on hydrology and soil conditions, and to modify the databases, which are used as a basis for scenario assessments.

The basic activity of the collaborative planning workshops was the formulation of alternative scenarios as inputs to a management regime adapted to local conditions. As such, it was a key aim to establish a genuine option to discuss and explore alternative futures in a creative and innovative process. A sense of scenario building as a tool to handle uncertainty should be promoted. The overall assessment was that these elements of the planning process were obtained relatively successfully. The challenge of involving stakeholders in a scenario building process was probably underestimated, as it proved difficult sometimes to boost the creative process. But, generally, the stakeholders were positively involved in the process.

A participatory process feeds on the engagement and experience of benefit for the effort among stakeholders. There must be incentives for participation, and the stakeholders must realize benefits that outweigh the costs of participating. A participation process should increase transparency and create a collaborative atmosphere. The evaluation process agreed that these criteria were met quite successfully, but it was noted that this is sometimes hard to measure.

The staging of the collaborative process in a local area requires the activation of existing local networks, but it is also crucial for a collaborative planning process to produce new relationships among stakeholders and raise the social capital locally. Not least the creation of contacts and networks across conflicting interest may prove valuable for obtaining results. Both the activation of existing networks and the creation of new ones were rated successfully. Necessary improvements mainly lie within the more deliberate activation of stakeholders and a more regular meeting frequency than what was possible in the given project context with our case studies.

Overall, the process is completely dependent on the support and understanding of collaborative planning. Based on the six case areas, this was generally rated as successful. The participants in most cases were offered a genuine participatory process, and the process was considered to be coordinated and managed effectively, in a neutral manner.

\subsection{Neutral一Room for Improvement}

Parameters evaluated as neutral (score $=3$ ) included various aspects of how problems, goals and aspirations were defined and understood among stakeholder, which often took place in a number of conflicting ways. Collaborative planning will often take place in a theatre of conflict; in fact, it is one of the virtues of collaborative planning that conflicts are addressed and that the process is aimed at creating consensus and solutions. Such planning processes will benefit from any degree of consensus on the common, initiating problem, shared purposes and incentives to participate and work towards consensus. It is considered a strength if there is a feeling of consensus among stakeholders on the goals. Ideally, a successful collaborative process reduces conflicts among stakeholders. In our process, it was revealed that there was not a strong sense of agreement on shared goals and the initiating problem. It was not a complete failure in the sense that agreement on the existence of an $\mathrm{N}$ problem was not reached, but there was no consensus on the magnitude and character of the problem. The stakeholders also did not share a common vision as to how the $\mathrm{N}$ problem should be solved. Many visions competed in local communities, and the few shared visions and thoughts of the local community represented by the stakeholders 
were more general wishes of an attractive local environment and strengthening of the local economic development.

The rather low degree of consensus on problems and goals was not an obstacle for the planning process per se, but the process would have been smoother if there had been more alignment among stakeholders.

Finally, it was a request that outcomes of the process served the public interest, but this criterion was not met to any significant degree. Probably more could have been done to reach the public by use of various media.

\subsection{Failures-Needs Complete Rethinking}

The least successful element of the planning process (score $=1$ and 2 ) was the degree of agreement reached among participants at the end of the process. There were no final plans to agree on, only alternative scenarios and visions expressed orally and spatially in maps. This was, to some extent, an effect of the method chosen, where we experimented with planning in ways that could not yet be realized, due to current legal restraints. We had anticipated this, expecting that the processes studied would not lead to a final agreement because this could only occur in the context of implementation options made impossible by existing regulatory requirements. As such, further experiments are needed to evaluate parameters dealing with finality, agreement and outcomes. Such experiments would have to take place in environments where existing regulation is made subject to the planning processes being tested, not vice versa. For example, as a consequence of legal mandates for the testing of alternative regulation being made available.

\section{Discussion}

\subsection{Selection of Evaluation Criteria}

The selection of evaluation criteria was obviously a critical issue in our process. We found good inspiration in previous examples of evaluating participatory processes, and found that it is of utmost importance that evaluation of the often complicated processes involved in planning is being done. The published studies, and the suggested criteria that had been tested in other situations, made a very fine point of departure for the selection of evaluation criteria.

A combination of the four cited nomenclatures proved to be a very suitable starting point. Based on our experiences, our general recommendation is that evaluation criteria should be developed prior to the planning process, thereby forcing managers of the planning process to formulate success criteria which can actually be met. In our case, focus was on the planning process before plans and alternative scenarios were formulated, not on implemented outcomes. Consequently, a rather large number of the cited criteria were not suitable or were irrelevant. This does not mean that these criteria are not relevant in other contexts. This evaluation should primarily be understood as input to the specific work of building planning and regulation methods that are spatially targeted and locally adapted, as is deemed needed in many agricultural landscapes in the developed world. Therefore, we focused specifically on the process of stakeholder identification, on the ability to create a collaborative atmosphere and the ability to provide adequate data and information and the prototype of a working technical solution. At a later stage, if collaborative planning is employed actively in regulation, there should be evaluation on the outcomes in terms of effects on the behaviour of farmers, on the quality of the environment and the added value for the local community of a comprehensive planning process.

The risk of being biased in a self-evaluation process is of course imminent. However, criteria pertaining to outcomes that were hard to judge were omitted, and criteria that would have included the evaluation of external partners were also excluded. Further evaluation of the planning process with a focus on the experience of stakeholders is currently being planned.

The results of our evaluation indicate that, seen as a whole, the participatory planning process was evaluated rather positively. However, this seemingly positive evaluation 
covers a significant variation among the six case areas. This variation was a prominent issue during the evaluation process. When discussing most evaluation criteria, the problem of giving an average rating of a criterion with six different case experiences as a basis was a source of doubt and ambiguity. Despite these reservations, there was a remarkable agreement among the two separate groups when rating the criteria individually.

\subsection{Participatory Planning as an Alternative to General Regulation}

The overall purpose of testing participatory planning processes was to clarify whether participatory planning can substitute or supplement general regulation approaches to reduce $\mathrm{N}$ emissions, and secondarily whether participatory planning can substitute or supplement statutory planning. An ultimate success criteria regarding the potential of participatory planning, as a substitute to general regulation, is that the former creates a more transparent process, more sustainable solutions and the same or better environmental effects as the latter. There are clear indications that participatory processes supported by data and computing power can increase transparency with regards to the analytical part of the planning process. In that regard, there is potential for inclusion of more detailed spatial data, which would thereby improve outcomes. The support for this is found in the positive evaluation of the inclusion of data and information and the ability to adopt local knowledge. Not least, the active engagement of farmers and citizens in creating solutions and the harvesting of local knowledge are obvious advantages in contrast to general regulation. The increased transparency gained in this way may be safeguarded by the use of open data sources, which may be modified by local input. While the process studied here could not be brought to the implementation phase, because it is experimenting with planning processes that are not yet supported institutionally and legally, the work with formulating scenarios indicate that environmental effects of the same order as those stemming from general regulation are likely to be achievable.

The planning process gave an indication of whether participatory planning can supplement or be an alternative to statutory planning. It can probably not stand alone, but may act as an important supplement. From an outcome perspective, it might require higher data quality with a higher resolution of observations appropriate to the scale of deliberative processes. Further, in order for the participatory planning process to be fruitful, the genuine inclusion of stakeholders must be taken seriously, as it can be argued that the perceived efficacy of social learning is an important prerequisite for the process to be successful [54].

A major advantage for the participatory approach and the local approach is the placemaking character of participatory planning. It proved a suitable approach, useful for staging the $\mathrm{N}$ problem as part of a broader set of issues centring on local development processes. As other studies have noted, collaborative planning allows for local stakeholders to question the scale of intervention and point towards needs to integrate concerns from otherwise separate policy domains $[55,56]$. The participatory process may be a good tool to integrate different interests in ways that statutory planning and sectorial regulation of $\mathrm{N}$ cannot accomplish.

In conclusion, there are no real reservations in our evaluation which discourage a collaborative approach to $\mathrm{N}$ management in small to medium size watersheds under the involvement of stakeholders. It should not be regarded as a quick fix though, as this kind of planning depend on time consuming negotiations and mediation. There is a concern with transaction costs being high, which is also reflected in the costs of this planning experiment. However, this has to be compared to the costs of the existing regulatory system, and compared to the value of negotiated, persistent solutions that are backed up by local stakeholders. To our knowledge, such estimates have not yet been subject to debate internationally.

In a collaborative planning process according to Healey, the scoping of the situation is a critical step [43]. The starting point for our planning case was the issue of $\mathrm{N}$ regulation in the farming sector to protect the quality of the aquatic environment. The specific reason for starting planning process experiments was the ongoing discourse on targeted regulation 
as a substitute for general regulation. This discourse had relevance for the entire rural community of Denmark, the farmers and related industries, along with authorities at all levels from municipal to national government and the EU. This external scoping of the planning situation encompasses the future of farming in local communities and on a national level. Use of $\mathrm{N}$ is a critical component of any farming system, and loss of $\mathrm{N}$ is a critical factor for deterioration of the natural environment. The collaborative approach offers a sound alternative or at least a supplement to other regulation alternatives in handling this challenge.

\subsection{Perspectives for Further Research: The Need for Real Life Testbeds}

Having stressed the potential suitability of participatory planning, it should further be emphasized that real life testing of this method is absolutely needed. This requires significant human and financial resources, but it must be taken into account that further improvements with regards to reducing $\mathrm{N}$ emissions may be hard to reach through mainstream regulatory instruments. Real life tests should be executed at a scale not very different from the one used in this study in order not to exceed a critical number of stakeholders. Furthermore, an important goal should be to reach agreements on specific action plans. This would be an important progression of the lessons learned in the present study.

\section{Conclusions}

In this article, we investigated how participatory planning processes dealing with land use management in agricultural landscapes characterized by high potentials for conflict can be evaluated. Based on empirical experience from six case study experiments in Danish landscapes aimed at identifying land use scenarios for reduced $\mathrm{N}$ emission from the agri-environment, we tested and assessed the usefulness of evaluation criteria identified in the literature. We conclude that appropriate evaluation criteria are characterized by addressing: (1) Processes of engagement, empowerment, ownership and place-making among stakeholders; (2) Information needs among stakeholders, including how data is collected, in what way estimates of actual and potential impacts of land use practices on the environment are shared, staged, framed, communicated and debated; (3) Whether processes of decision making are focused to ensure promotion of flexible, permissive meetings between stakeholders in ways that invite the articulation of inclusive, spatially explicit solution proposals at relevant scales; (4) Whether local expertise, knowhow, experience, priorities and imperatives are taken into account in an earnest and explicit way to ensure that general, scientific expertise is used to enrich rather than challenge other types of contributions to solution identification; (5) Whether the facilitation of decision making processes succeed in creating a creative and explorative process unfolding ideas, dreams and aspirations in combination with limitations and needs. We conclude that in agricultural landscapes where reduction of $\mathrm{N}$ emissions is a shared concern and where landscape conditions make decision making at spatial scales above that of individual farm holdings necessary or attractive to stakeholders, participatory planning represents a viable way to target regulation as an alternative to top-down oriented regulatory approaches. Targets for reduction of $\mathrm{N}$ emissions developed in participatory processes are characterized by being oriented towards solutions and socio-ecological imperatives rather than limitations and requirements. As such, participatory planning interventions hold the potential to facilitate endogenous, innovative solution identification processes among stakeholders in ways that foster the articulation of localized, adaptive plans for $\mathrm{N}$ reduction. Our results indicate that evaluation of participatory planning processes will profit from including such criteria. 
Author Contributions: All of the authors contributed substantially to the research in various capacities, as reflected in the sequence of authorships. Concept development, research design, empirical work, analysis and reporting was a joint effort. Conceptualization, A.A.C., P.S.A., C.K., M.G., E.A., J.E.O. and H.V.; data curation, A.A.C., C.K., M.G., E.A. and T.D.; formal analysis, A.A.C., P.S.A., T.D. and H.V.; funding acquisition, T.D. and H.V.; investigation, A.A.C., P.S.A., M.G., K.P. and H.V.; methodology, A.A.C., P.S.A., M.G., E.A., K.P. and H.V.; project administration, T.D., J.E.O. and H.V.; resources, P.S.A. and H.V.; software, A.A.C.; supervision, E.A., J.E.O. and H.V. All authors have read and agreed to the published version of the manuscript.

Funding: This work was supported by the www.dnmark.org (accessed on 12 September 2020) Strategic Research Alliance (DNMARK: Danish Nitrogen Mitigation Assessment: Research and Know-how for a sustainable, low-Nitrogen food production (2013-2017), www.dNmark.org (accessed on 12 September 2020), funded by The Danish Council for Strategic Research (Ref. 12-132421)/Innovationsfonden.

Informed Consent Statement: Informed consent was obtained from all subjects involved in the study.

Data Availability Statement: The data presented in this study are available on request from the corresponding author.

Conflicts of Interest: The authors declare no conflict of interest. The funders had no role in the design of the study; in the collection, analyses, or interpretation of data; in the writing of the manuscript, or in the decision to publish the results.

\section{References}

1. United Nations. Resilient People, Resilient Planet: A Future Worth Choosing, the Report of the United Nations Secretary-General's High Level Panel on Global Sustainability; United Nations: New York, NY, USA, 2012; ISBN 978-92-1-101256-9.

2. Rockström, J.; Williams, J.; Daily, G.; Noble, A.; Matthews, N.; Gordon, L.; Wetterstrand, H.; DeClerck, F.; Shah, M.; Steduto, P.; et al. Sustainable intensification of agriculture for human prosperity and global sustainability. Ambio 2017, 46, 4-17. [CrossRef] [PubMed]

3. Matson, P.A.; Parton, W.J.; Power, A.G.; Swift, M.J. Agricultural intensification and ecosystem properties. Science 1997, 277, 504-509. [CrossRef]

4. Grizzetti, B.; Bouraoui, F.; Billen, G.; van Grinsven, H.; Cardoso, A.C.; Thieu, V.; Garnier, J.; Curtis, C.; Howarth, R.; Johnes, P. Nitrogen as a threat to European water quality. In The European Nitrogen Assessment; Sutton, M.A., Howard, C.M., Erisman, J.W., Billen, G., Bleeker, A., Grennfelt, P., van Grinsven, H., Grizzetti, B., Eds.; Cambridge University Press: Cambridge, UK, 2011; pp. 379-404. ISBN 978-0-511-97698-8.

5. Kanter, D.R.; Chodos, O.; Nordland, O.; Rutigliano, M.; Winiwarter, W. Gaps and opportunities in nitrogen pollution policies around the world. Nat. Sustain. 2020, 3, 1-8. [CrossRef]

6. Hellsten, S.; Dalgaard, T.; Rankinen, K.; Tørseth, K. Nordic Nitrogen and Agriculture: Policy, Measures and Recommendations to Reduce Environmental Impact; Nordic Council of Ministers: Copenhagen, Denmark, 2017; ISBN 978-92-893-5087-7.

7. Kronvang, B.; Andersen, H.E.; Børgesen, C.; Dalgaard, T.; Larsen, S.E.; Bøgestrand, J.; Blicher-Mathiasen, G. Effects of policy measures implemented in Denmark on nitrogen pollution of the aquatic environment. Environ. Sci. Policy 2008, 11, 144-152. [CrossRef]

8. Schrøder, H. Nitrogen losses from Danish agriculture-trends and consequences. Agric. Ecosyst. Environ. 1985, 14, 279-289. [CrossRef]

9. The Danish Environmental Protection Agency. Implementation of the Nitrates directive in Denmark. Available online: https: // eng.mst.dk/trade/agriculture/nitrates-directive/implementation-in-denmark/ (accessed on 12 September 2020).

10. Daugbjerg, C.; Pedersen, A.B. New Policy Ideas and Old Policy Networks: Implementing Green Taxation in Scandinavia. J. Public Policy 2004, 24, 219-249. [CrossRef]

11. Dalgaard, T.; Hansen, B.; Hasler, B.; Hertel, O.; Hutchings, N.J.; Jacobsen, B.H.; Stoumann Jensen, L.; Kronvang, B.; Olesen, J.E.; Schjørring, J.K.; et al. Policies for agricultural nitrogen management-trends, challenges and prospects for improved efficiency in Denmark. Environ. Res. Lett. 2014, 9, 115002. [CrossRef]

12. OECD. Evaluating Agri-environmental Policies: Design, Practice and Results; OECD: Paris, France, 2005; ISBN 978-92-64-01010-9.

13. Graversgaard, M.; Hedelin, B.; Smith, L.; Gertz, F.; Højberg, A.L.; Langford, J.; Martinez, G.; Mostert, E.; Ptak, E.; Peterson, H.; et al. Opportunities and Barriers for Water Co-Governance-A Critical Analysis of Seven Cases of Diffuse Water Pollution from Agriculture in Europe, Australia and North America. Sustainability 2018, 10, 1634. [CrossRef]

14. Danish Ministry of the Environment. The Planning Act Consolidated Act No. 813 of 21 June 2007; Danish Ministry of the Environment: Copenhagen, Denmark, 2017.

15. Kristensen, L.S.; Primdahl, J.; Vejre, H. Dialogbaseret Planlaegning i det Aabne Land: Om Strategier for Kulturlandskabets Fremtid [Dialogue Based Countryside Planning_Strategies for the Future of Cultural Landscapes]; Bokvaerket: Copenhagen, Denmark, 2016; ISBN 978-87-92420-35-0.

16. EU Commission. The Nitrate Directive; EU Commission: Luxembourg, 1991. 
17. Danish Ministry of the Environment and Food. The Nature Protection Act. Consolidated Act no. 240 af 13. March 2019; Danish Ministry of the Environment and Food: Copenhagen, Denmark, 2019.

18. EU Commission. The Habitats Directive; EU Commission: Luxembourg, 1992.

19. EU Commission. The Water Framework Directive; EU Commission: Luxembourg, 2000.

20. Thorsøe, M.H.; Graversgaard, M.; Noe, E. The challenge of legitimizing spatially differentiated regulation: Experiences from the implementation of the Danish Buffer zone act. Land Use Policy 2017, 62, 202-212. [CrossRef]

21. Commission on Nature and Agriculture. Nature and Agriculture-A New Start; Secretariat of the Commission of Nature and Agriculture: Copenhagen, Denmark, 2013.

22. Christensen, A.A.; Andersen, P.S.; Piil, K.; Andersen, E.; Vejre, H.; Graversgaard, M. Pursuing implementation solutions for targeted nitrogen management in agriculture-A novel approach to synthesize knowledge and facilitate sustainable decision making based on collaborative landscape modelling. J. Environ. Manag. 2019, 246, 679-686. [CrossRef] [PubMed]

23. Andersen, P.S.; Andersen, E.; Graversgaard, M.; Christensen, A.A.; Vejre, H.; Dalgaard, T. Using landscape scenarios to improve local nitrogen management and planning. J. Environ. Manag. 2019, 232, 523-530. [CrossRef] [PubMed]

24. Kristensen, L.S.; Primdahl, J. Nye tilgange til det åbne lands planlægning-Praktiske og teoretiske udgangspunkter [New approaches to countryside planning_Practical and theoretical starting points]. In Dialogbaseret Planlægning i det Åne Land: Om strategier for Kulturlandskabets Fremtid; Kristensen, L.S., Primdahl, J., Vejre, H., Eds.; Bokværket: Copenhagen, Denmark, 2016; ISBN 978-87-92420-35-0.

25. Fertner, C.; Aagaard Christensen, A.; Andersen, P.S.; Olafsson, A.S.; Præstholm, S.; Caspersen, O.H.; Grunfelder, J. Emerging digital plan data-New research perspectives on planning practice and evaluation. Geogr. Tidsskrift-Dan. J. Geogr. 2019, 119, 6-16. [CrossRef]

26. Graversgaard, M.; Thorsøe, M.H.; Kjeldsen, C.; Dalgaard, T. Evaluating public participation in Denmark's water councils: How policy design and boundary judgements affect water governance! Outlook Agric. 2016, 45, 225-230. [CrossRef]

27. Sebastien, L. From NIMBY to enlightened resistance: A framework proposal to decrypt land-use disputes based on a landfill opposition case in France. Local Environ. 2017, 22, 461-477. [CrossRef]

28. Svenningsen, S.R.; Brandt, J.; Christensen, A.A.; Dahl Hansen, M.; Dupont, H. Historical oblique aerial photographs as a powerful tool for communicating landscape changes. Land Use Policy 2015, 43, 82-95. [CrossRef]

29. EU Commission. The Aarhus Convention; Commission: Luxembourg, 2001.

30. Bentrup, G. Evaluation of a Collaborative Model: A Case Study Analysis of Watershed Planning in theIntermountain West. Environmental Management 2001, 27, 739-748. [CrossRef] [PubMed]

31. Vejre, H.; Vesterager, J.P.; Andersen, P.S.; Olafsson, A.S.; Brandt, J.; Dalgaard, T. Does cadastral division of area-based ecosystem services obstruct comprehensive management? Ecol. Model. 2015, 295, 176-187. [CrossRef]

32. Murgue, C.; Therond, O.; Leenhardt, D. Toward integrated water and agricultural land management: Participatory design of agricultural landscapes. Land Use Policy 2015, 45, 52-63. [CrossRef]

33. Hägerstrand, T. A Look at the Political Geography of Environmental Management. In Sustainable Landscapes and Lifeways-Scale and Appropriateness; Buttimer, A., Ed.; Cork University Press: Cork, Ireland, 2001; pp. 35-58.

34. Wheale, P.R.; Amin, L.H. The polluter pays principle: An assessment of various economic instruments' for the control of pollution. New Acad. Rev. 2003, 4, 38-60.

35. Vejre, H.; Vesterager, J.P.; Kristensen, L.S.; Primdahl, J. Stakeholder and expert-guided scenarios for agriculture and landscape development in a groundwater protection area. J. Environ. Plan. Manag. 2011, 54, 1169-1187. [CrossRef]

36. Christensen, A.A. Using Interactive Modeling Tools to Engage with, Inform and Empower Decision Making in Local Communities of Landscape Managers; Paper presented at the IALE 2017 European Landscape Ecology Congress; Ghent University: Ghent, Belgium, 2017.

37. Christensen, A.A.; Piil, K.; Andersen, P.S.; Andersen, E.; Vejre, H. Designing decision support tools for targeted N-regulation: Experiences from developing and using the Danish dNmark landscape model. In Proceedings of the Innovative Solutions for Sustainable Management of Nitrogen—Conference Proceedings; Aarhus University: Aarhus, Denmark, 2017; p. 59.

38. Marsden, T.K. Third natures: Reconstituting space through place-making strategies for sustainability. Int. J. Soc. Agric. Food 2012, $19,257-274$.

39. Goldstein, B.E.; Butler, W.H. Expanding the Scope and Impact of Collaborative Planning: Combining Multi-Stakeholder Collaboration and Communities of Practice in a Learning Network. J. Am. Plan. Assoc. 2010, 76, 238-249. [CrossRef]

40. Kroon, F.J.; Robinson, C.J.; Dale, A.P. Integrating knowledge to inform water quality planning in the Tully-Murray basin, Australia. Mar. Freshw. Res. 2009, 60, 1183. [CrossRef]

41. Agger, A.; Hoffmann, B.; Danmark Velfærdsministeriet. Borgerne på Banen; Velfærdsministeriet: Copenhagen, Denmark, 2008; ISBN 978-87-7546-420-3.

42. Habermas, J.; MacCarthy, T. Lifeworld and System: A Critique of Functionalist Reason; Beacon: Boston, MA, USA, 2005; ISBN 0-8070-1400-1.

43. Healey, P. The communicative Turn in Planning-Theory and its Implications for Spatial Strategy Formation. In Readings in Planning Theory; Campbell, S., Fainstein, S.S., Eds.; Blackwell Publishing: Oxford, UK, 2003; pp. 237-255.

44. Christensen, A.A. Agrarian Landscape Management in a Modernized World. Ph.D. Thesis, Department of Geosciences and Natural Resource Management, Faculty of Science, University of Copenhagen, Copenhagen, Denmark, 2016. 
45. Nellemann, V.; Møller, K.H.; Møller, P.G.; Primdahl, J.; Øberg, A.S. Strategi for Karby Sogn: Landskab og landsby [Strategy for Karby Parish-landscape and village]. In Dialogbaseret Planlægning $i$ det Åbne Land: Om Strategier for Kulturlandskabets Fremtid; Kristensen, L.S., Primdahl, J., Vejre, H., Eds.; Bokværket: Copenhagen, Denmark, 2016; ISBN 978-87-92420-35-0.

46. Swaffield, S.; Primdahl, J. Spatial Concepts in Landscape Analysis and Policy: Some Implications of Globalisation. Land. Ecol. 2006, 21, 315-331. [CrossRef]

47. Christensen, A.A. Modern Agricultural Landscapes-A Perspective on Their Past, Present and Future. In Proceedings of the 2nd International Conference of IALE Iran, Isfahan, Iran, 14-17 October 2009.

48. Primdahl, J.; Kristensen, L.S. The farmer as a landscape manager: Management roles and change patterns in a Danish region. Geogr. Tidsskrift-Dan. J. Geogr. 2011, 111, 107-116. [CrossRef]

49. Linnenluecke, M.K.; Verreynne, M.-L.; de Villiers Scheepers, M.J.; Venter, C. A review of collaborative planning approaches for transformative change towards a sustainable future. J. Clean. Produc. 2017, 142, 3212-3224. [CrossRef]

50. Flyvbjerg, B. Five Misunderstandings About Case-Study Research. Qual. Inq. 2006, 12, 219-245. [CrossRef]

51. Faehnle, M.; Tyrväinen, L. A framework for evaluating and designing collaborative planning. Land Use Policy 2013, 34, 332-341. [CrossRef]

52. Vacik, H.; Kurttila, M.; Hujala, T.; Khadka, C.; Haara, A.; Pykäläinen, J.; Honkakoski, P.; Wolfslehner, B.; Tikkanen, J. Evaluating collaborative planning methods supporting programme-based planning in natural resource management. J. Environ. Manag. 2014, 144, 304-315. [CrossRef] [PubMed]

53. Cullen, D.; McGee, G.J.A.; Gunton, T.I.; Day, J.C. Collaborative Planning in Complex Stakeholder Environments: An Evaluation of a Two-Tiered Collaborative Planning Model. Soc. Nat. Res. 2010, 23, 332-350. [CrossRef]

54. Leeuwis, C.; Ban, A.W. Communication for Rural Innovation: Rethinking Agricultural Extension, 3rd ed.; Blackwell Science: Hoboken, NJ, USA; Iowa State Press: Ames, IA, USA, 2003; ISBN 978-0-632-05249-3.

55. Krzywoszynska, A.; Buckley, A.; Birch, H.; Watson, M.; Chiles, P.; Mawyin, J.; Holmes, H.; Gregson, N. Co-producing energy futures: Impacts of participatory modelling. Build. Res. Inform. 2016, 44, 804-815. [CrossRef]

56. Krzywoszynska, A.; Matt, W.; Buckley, A.; Chiles, P.; Gregson, N.; Holmes, H.; Mawyin, J. Opening Up the Participation Laboratory: The Cocreation of Publics and Futures in Upstream Participation. Sci. Technol. Human Values 2018, 43, 785-809. [CrossRef] 